\title{
PENGARUH UMUR POHON INDUK TERHADAP PERAKARAN STEK NYAMPLUNG (Calophyllum inophyllum L.)
}

\author{
The Effect of Mother Tree Age on Root Formation of Nyamplung \\ (Calophyllum inophyllum L.) Cuttings \\ Danu ${ }^{1)}$, Atok Subiakto ${ }^{2)}$ dan A.Z. Abidin ${ }^{1)}$ \\ ${ }^{1)}$ Peneliti di Balai Penelitian Teknologi Perbenihan, Bogor \\ Jl. Pakuan, Ciheuleut PO Box 105 Bogor 16001, Telp./Fax. (0251) 8327768 \\ ${ }^{2)}$ Peneliti di Pusat Penelitian dan Pengembangan Konservasi dan Rehabilitasi, Bogor \\ Jl. Gunung Batu No. 5 Bogor 16610, Telp. (0251) 8633234, Fax. (0251) 8633111
}

Naskah masuk : 28 Januari 2010; Naskah diterima : 10 Januari 2011

\begin{abstract}
Nyamplung (Calophyllum inophyllum $L$.) seeds are one of the most promising source of high quality biodiesel. Moreover, their woods are good for sea vessel making and other purposes. The tree is evergreen and grows naturaly along coastal area. The seeds are recalsitrant which can not be stored for long period of time. Vegetative propagation is one of the promising techniques for overcoming this problem. The research was conducted to study root formation from three different age group of cutting source i.e. (a) seedlings (juvenile stage), (b) young sapling (not fruiting yet), and (c) mature trees. The rooting percentage of the cutting from seedling can produce as much as $75 \%$ with $14.54 \mathrm{~cm}$ root length, root number of 15 units per cuttings and root biomass of 0.132 grams per cuttings; the cutting material from young sapling tree can produce as much as 25\% rooted cuttings with roots $9.67 \mathrm{~cm}$ long, 10 pieces per number of root cuttings, and root biomass of 0.094 grams per cuttings; and the cutting material from mature trees to produce rooted cuttings of $16.11 \%$ with $8.54 \mathrm{~cm}$ root length, number of roots of 9 per cuttings, root biomass of 0.10 grams per cuttings. The difference between the percentage of rooting cuttings materials is caused by auxin content and $C / N$ ratio. Materials from younger cuttings tend to contain a high auxin (96.86 ppm) with C/N ratio of 63.73.
\end{abstract}

\section{Key words: Age of cuttings source, nyamplung}

\begin{abstract}
ABSTRAK
Tanaman nyamplung (Calophyllum inophyllum L.) merupakan salah satu tanaman yang dapat menghasilkan buah sebagai bahan minyak nabati kualitas tinggi. Selain itu, kayunya dapat digunakan sebagai bahan pembuatan perahu dan keperluan lainnya. Pohon ini tumbuh alami di pesisir pantai dan tidak menggugurkan daun. Benihnya tergolong rekalsitran sehingga benihnya tidak dapat disimpan lama. Perbanyakan vegetatif merupakan salah satu teknik untuk mengatasi masalah ini. Penelitian ini bertujuan untuk mempelajari perakaran dari tiga kelompok umur bahan stek yaitu: (a) anakan, (b) pancang (belum berbuah), (c) pohon dewasa. Bahan stek nyamplung asal anakan dapat menghasilkan stek berakar sebanyak $75 \%$ dengan panjang akar 14,54 cm, jumlah akar 15 buah per stek dan biomasa akar 0,132 gram per stek. Bahan stek nyamplung asal pancang dapat menghasilkan stek berakar sebanyak $25 \%$ dengan panjang akar 9,67 cm, jumlah akar 10 buah per stek, dan biomasa akar 0,094 gram per stek. Bahan stek nyamplung asal pohon dewasa dapat menghasilkan stek berakar $16,11 \%$ dengan panjang akar $8,54 \mathrm{~cm}$, jumlah akar 9 buah per stek, biomasa akar 0,10 gram per stek. Perbedaan persentase perakaran antara bahan stek disebabkan kandungan auksin dan nisbah $\mathrm{C} / \mathrm{N}$. Bahan stek yang lebih muda cenderung mengandung auksin yang tinggi (96,86 ppm) dengan nisbah $\mathrm{C} / \mathrm{N}$ sebesar 63,73.
\end{abstract}

\section{Kata kunci: Umur tanaman sumber bahan stek, nyamplung}




\section{PENDAHULUAN}

\section{A. Latar Belakang}

Pohon nyamplung (Calophyllum inophyllum L.) merupakan salah satu tanaman pesisir yang memiliki nilai ekonomi tinggi sebagai sumber penghasil energi. Buahnya dapat menghasilkan bahan bakar nabati yang berkualitas tinggi dan minyak tamanu (Bustomi et al., 2008; Rostiwati dan Heryati, 2007; Salminah, 2007), sedangkan kayunya dapat digunakan sebagai bahan pembuatan perahu, balok, tiang, papan lantai dan kontruksi ringan (Heyne, 1987; Mandang dan Yetty, 1990). Dengan demikian, jenis ini sangat potensial untuk dikembangkan sebagai tanaman hutan rakyat kayu dan rehabilitasi lahan daerah pesisir.

Benih nyamplung tergolong benih semirekalsitran (cepat rusak) dan memiliki kulit biji yang keras sehingga dalam perkecambahannya memerlukan teknologi skarifikasi dan stratifikasi khusus. Metoda perbanyakan secara vegetatif dapat membantu untuk memperbanyak tanaman yang memiliki kesulitan dalam memperoleh buah dan biji, benihnya cepat rusak, melestarikan klon tanaman unggul dan untuk memudahkan serta mempercepat perbanyakan tanaman (Rochiman dan Harjadi, 1973). Selain itu metoda ini sangat membantu dan mendorong dalam proses pemuliaan pohon (Zobel dan Talbert, 1984).

Perbanyakan tanaman secara vegetatif dapat dilakukan secara stek, grafting, cangkok dan kultur jaringan. Cara stek dan kultur jaringan sangat baik untuk memperbanyak tanaman secara masal. Cara grafting dan cangkok dapat dipergunakan untuk pengadaan bahan tanaman untuk pembangunan kebun benih maupun bank klon. Cara stek dan grafting merupakan teknik perbanyakan vegetatif yang lebih efektif dan efisien, karena dalam pelaksanaannya lebih mudah dan murah dibandingkan dengan teknik kultur jaringan dan cangkok.

Pertumbuhan stek dipengaruhi oleh interaksi faktor genetik dan faktor lingkungan (Hartmann et al. 1997). Faktor genetik terutama meliputi kandungan cadangan makanan dalam jaringan stek, ketersediaan air, umur tanaman (pohon induk), hormon endogen dalam jaringan stek, dan jenis tanaman. Faktor lingkungan yang mempengaruhi keberhasilan penyetekan, antara lain: media perakaran, kelembaban, suhu, intensitas cahaya dan teknik penyetekan.

\section{B. Tujuan Penelitian}

Mengetahui pengaruh umur sumber bahan stek dan zat pengatur tumbuh terhadap keberhasilan perakaran stek nyamplung.

\section{METODE PENELITIAN}

\section{A. Lokasi Penelitian}

Lokasi Penelitian di Laboratorium Silvikultur Pusat Penelitian dan Pengembangan Hutan dan Konservasi Alam, Gunungbatu, Bogor. Penelitian dimulai bulan Februari 2009 Desember 2009.

\section{B. Bahan dan Alat yang digunakan}

Bahan stek nyamplung dikumpulkan dari tanaman rakyat di Batukaras, Cijulang, Ciamis dengan tiga kelas umur yaitu anakan (diameter $4,09 \pm 0,70 \mathrm{~mm}$ dan tinggi $24,70 \pm 4,24 \mathrm{~cm}$ ), pohon muda (pohon belum berbuah diameter $3,52 \pm 2,12 \mathrm{~cm}$ dan tinggi 2,94 $\pm 0,48 \mathrm{~m}$ ), dan pohon dewasa (pohon sudah berbuah, diameter $21,40 \pm 4,80 \mathrm{~cm}$ dan tinggi $10,65 \pm 2,10 \mathrm{~m}$ ).

\section{Prosedur Penelitian}

\section{Perbanyakan Vegetatif Stek Jenis Nyamplung}

Bahan stek pucuk nyamplung dipotong dengan ukuran minimal 2 ruas daun atau (3 nodul). Daun-daun bahan stek yang telah diambil tanaman induk dipotong separuhnya dan tunas atau daun muda (shoot tip) dibuang, kemudian diberi zat pengatur tumbuh sesuai perlakuan. Bahan stek ditanam pada media dalam pot-tray yang berisi campuran sabut kelapa dan sekam padi steril dengan perbandingan $2: 1(\mathrm{v} / \mathrm{v})$. Pottray diberi label yang berisi tanggal penanaman, kemudian diletakan pada rumah kaca yang dilengkapi dengan sistem pendingin (cooling system) atau ruang KOFFCO.

Penelitian menggunakan rancangan acak lengkap (RAL) pola faktorial dengan dua faktor. Faktor pertama (A) adalah sumber bahan stek (pohon induk) stek yang meliputi : $\mathrm{A}_{1}=$ anakan; $\mathrm{A}_{2}=$ pohon muda (pohon belum berbuah); dan $\mathrm{A}_{3}=$ pohon dewasa (pohon sudah berbuah). Faktor kedua (B) adalah jenis dan konsentrasi zat pengatur tumbuh yang meliputi : $\mathrm{B}_{1}$ kontrol (tanpa zat pengatur tumbuh); $\mathrm{B}_{2}=$ Rootone- $\mathrm{F}$ (pasta); $\mathrm{B}_{3}=I B A 100$ ppm; $\mathrm{B}_{4}=200 \mathrm{ppm} ; \mathrm{B}_{5}=$ 
$500 \mathrm{ppm} ; \mathrm{B}_{6}=$ IBA $1000 \mathrm{ppm}$. Setiap perlakuan diulang 3 kali dan setiap ulangan terdiri dari 45 stek. Respon pertumbuhan yang diamati meliputi: persentase hidup, persentase bertunas, persentase berakar, persentase bertunas-berakar, panjang akar, jumlah akar dan biomasa akar.

\section{Analisis Hara dan Auksin Bahan Stek}

Bahan stek sebelum diberi perlakuan diukur unsur haranya meliputi unsur karbon (C), nitrogen $(\mathrm{N})$, dan nisbah $\mathrm{C} / \mathrm{N}$ (Tabel 1). Pengujian kandungan hara dilakukan di
Laboratorium Departemen Ilmu Tanah dan Sumberdaya Lahan, Fakultas Pertanian IPB. Kandungan $\mathrm{C}$ ditetapkan dengan menggunakan metode C-Mobius, sedangkan unsur $\mathrm{N}$ ditetapkan menggunakan metode Kjeldahl. Nisbah $\mathrm{C} / \mathrm{N}$ dihitung berdasarkan kandungan unsur $\mathrm{C}$ dan $\mathrm{N}$ bahan stek.

Kandungan auksin diukur dengan menggunakan HPLC (high performance liquid chromatography) dengan detektor UV-Vis di Laboratorium Pengujian, Balai Besar Penelitian dan Pengembangan Pascapanen Pertanian dengan metode Linskens dan Jackson (1987).

Tabel(Table) 1. Kandungan auksin dan hara dalam bahan stek (The auxin and nutrient contents of the cutting material)

\begin{tabular}{|c|l|c|c|c|c|}
\hline \multirow{2}{*}{ No. } & \multirow{2}{*}{$\begin{array}{c}\text { Umur pohon induk bahan stek } \\
\text { (Age of mother tree of cutting } \\
\text { material) }\end{array}$} & \multicolumn{3}{|c|}{ Kandungan hara (Auxin and nutrient content) } \\
\cline { 3 - 6 } & & $\begin{array}{c}\text { Auxin } \\
(\mathrm{ppm})\end{array}$ & $\begin{array}{c}\mathrm{C} \\
(\%)\end{array}$ & $\begin{array}{c}\mathrm{N} \\
(\%)\end{array}$ & $\mathrm{C} / \mathrm{N}$ \\
\hline 1 & Anakan (seedling) & $96,86^{\mathrm{a}}$ & $55,28^{\mathrm{a}}$ & $0,87^{\mathrm{b}}$ & $63,73^{\mathrm{a}}$ \\
\hline 2 & Pohon muda (Juvenile tree) & $92,63^{\mathrm{b}}$ & $55,39^{\mathrm{a}}$ & $1,03^{\mathrm{ab}}$ & $53,71^{\mathrm{b}}$ \\
\hline 3 & Pohon dewasa (Mature tree) & $81,62^{\mathrm{c}}$ & $55,43^{\mathrm{a}}$ & $1,13^{\mathrm{a}}$ & $49,43^{\mathrm{b}}$ \\
\hline
\end{tabular}

Keterangan (Remark): Angka yang diikuti oleh huruf yang sama tidak berbeda nyata pada taraf uji 5\% (DMRT) (Values in rows followed by the same letter are not significantly different at level of $5 \%$ base on Duncan Multiple Range test)

\section{Analisis Data}

Data pertumbuhan stek yang diperoleh dianalisis keragamannya dan diuji perbedaanya dengan menggunakan uji beda jarak Duncan.

\section{HASIL DAN PEMBAHASAN}

\section{A. Pengaruh Umur Sumber Bahan Stek dan Hormon Tumbuh terhadap Perakaran Stek Nyamplung}

Hasil analisis sidik ragam menunjukkan bahwa umur pohon induk bahan stek sangat berpengaruh terhadap persen hidup, persen tunas, persen akar, panjang akar, jumlah akar, biomasa akar stek nyamplung. Pemberian hormon tumbuh rootne-F dan IBA 100 ppm, 200 ppm, 500 ppm dan $1000 \mathrm{ppm}$ tidak berpengaruh nyata terhadap perakaran stek nyamplung pada taraf uji 0,5 . Hormon tumbuh IBA dengan konsentrasi ini belum efektif dalam meningkatkan pertumbuhan akar stek nyamplung (Tabel 2 dan Gambar 1). 
Tabel(Table) 2. Rekapitulasi nilai F hitung pengaruh perlakukan umur bahan stek dan hormon tumbuh terhadap rata-rata persen hidup persen berakar, jumlah dan panjang akar serta biomasa akar stek nyamplung umur 3 bulan (The effect of growth regulator and cutting source on growth parameters of the cuttings)

\begin{tabular}{|c|c|c|c|c|c|c|c|c|}
\hline \multirow[b]{2}{*}{$\begin{array}{l}\text { Sumber Keragaman } \\
\text { (Source of variation) }\end{array}$} & \multicolumn{6}{|c|}{ F Hitung (F-calculation) } & \multicolumn{2}{|c|}{$\begin{array}{l}\text { F Tabel } \\
(F \text { table })\end{array}$} \\
\hline & $\begin{array}{c}\text { Persen } \\
\text { hidup } \\
\text { (Survival } \\
\text { per- } \\
\text { centage) }\end{array}$ & $\begin{array}{c}\text { Persen } \\
\text { tunas } \\
\text { (Shoot per- } \\
\text { centage) }\end{array}$ & $\begin{array}{c}\text { Persen } \\
\text { akar } \\
\text { (Root per- } \\
\text { centage) }\end{array}$ & $\begin{array}{l}\text { Panjang } \\
\text { akar } \\
\text { (Length } \\
\text { of root) }\end{array}$ & $\begin{array}{l}\text { Jumlah } \\
\text { akar } \\
\text { (Number } \\
\text { of root) }\end{array}$ & $\begin{array}{c}\text { Biomasa } \\
\text { akar } \\
\text { (Biomassa } \\
\text { of root) }\end{array}$ & 0,5 & 0,1 \\
\hline $\begin{array}{l}\text { Bahan stek } \\
\text { (Cuttings material) } \\
\text { (A) }\end{array}$ & $15,37 * *$ & $15,92 * *$ & $142,93 * *$ & $21,60 * *$ & $9,85 * *$ & 3,15 & 3,32 & 5,39 \\
\hline $\begin{array}{l}\text { Zat Pengatur } \\
\text { Tumbuh (Growth } \\
\text { regulator) (B) }\end{array}$ & 2,35 & 1,17 & 2,34 & 1,25 & 1,38 & 0,74 & 2,53 & 3,70 \\
\hline $\begin{array}{l}\text { Interaksi } \\
\text { (Interaction) } \\
(\mathrm{A} \times \mathrm{B})\end{array}$ & 1,55 & 0,33 & 1,71 & 1,08 & 0,66 & 0,59 & 2,17 & 2,98 \\
\hline
\end{tabular}

Keterangan (Remark): th = tidak nyata pada taraf uji 0,05 (not significantly at 0,05 level)

* = nyata pada taraf uji 0,05 (significantlyat 0,05 level)

** = sangat nyata taraf uji 0,01 (significantlyat 0.01 level)

Bahan stek berasal dari tingkat anakan lebih mudah bertunas dan berakar dibandingkan dengan bahan stek dari pohon muda (belum berbuah) dan pohon dewasa (sudah berbuah). Selain itu, bahan stek yang berasal dari tanaman induk muda memiliki panjang akar dan jumlah akar yang lebih tinggi dibandingkan dengan stek dari tanaman dewasa (Tabel 3, Gambar 1), sedangkan bahan stek yang berasal dari pohon muda dan dewasa memiliki tingkat keberhasilan relatif sama. 
$\left(A_{1}\right)$

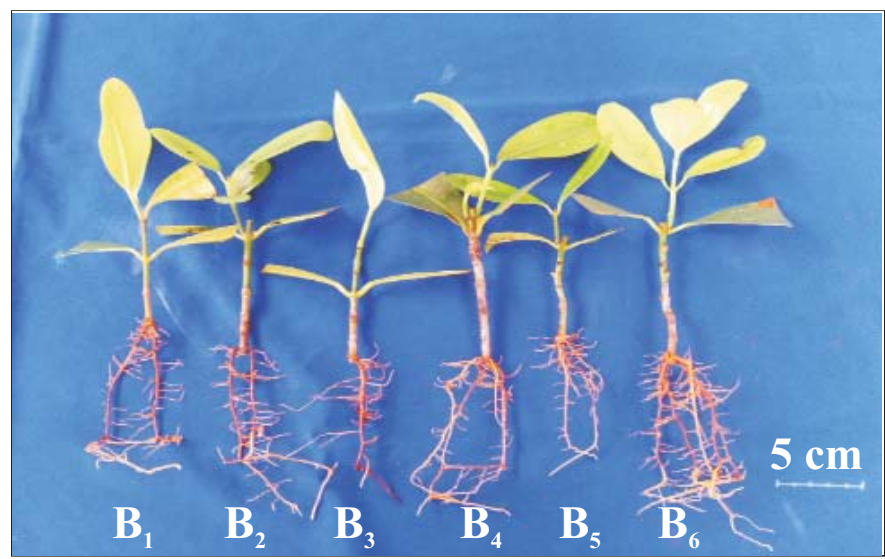

$\left(\mathrm{A}_{2}\right)$

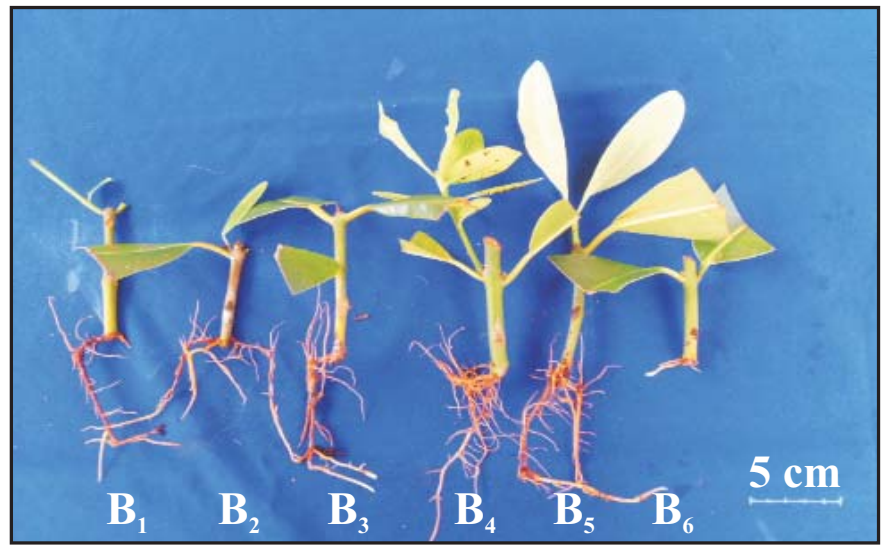

$\left(\mathrm{A}_{3}\right)$

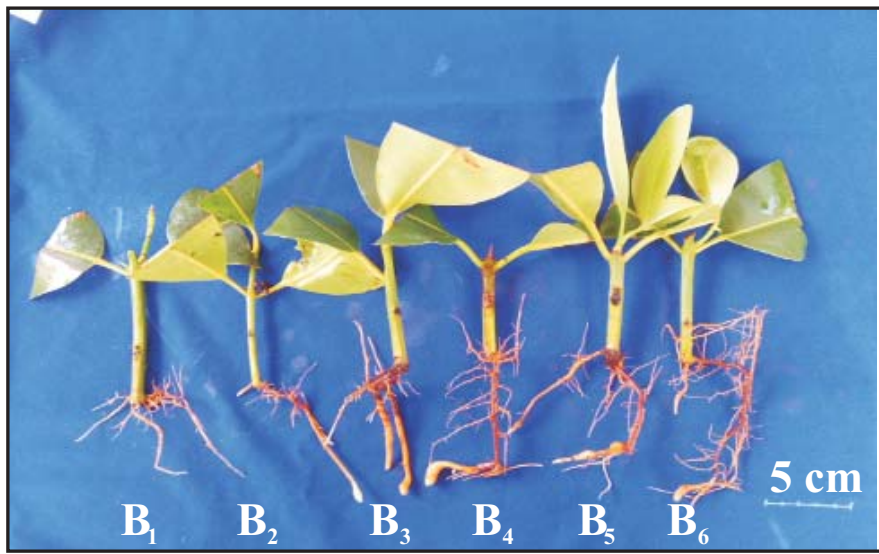

Gambar(Figure) 1. Stek nyamplung umur 3 bulan setelah tanam; $\left(\mathrm{A}_{1}\right)$ : bahan stek asal anakan, $\left(\mathrm{A}_{2}\right)$ : bahan stek asal pohon muda, $\left(\mathrm{A}_{3}\right)$ : bahan stek asal pohon dewasa; konsentrasi zat pengatur tumbuh akar $\mathrm{B}_{1}$ :kontrol, $\mathrm{B}_{2}$ : rootone-F, $\mathrm{B}_{3}$ : IBA $100 \mathrm{ppm}, \mathrm{B}_{4}: \mathrm{IBA} 200 \mathrm{ppm}$, $\mathrm{B}_{5}=\mathrm{IBA} 500 \mathrm{ppm}, \mathrm{B}_{6}=\mathrm{IBA} 1000 \mathrm{ppm}$. (Nyamplung cuttings were 3 months old after planted; $\left(A_{1}\right)$ : cuttings material from seedling, $\left(A_{2}\right)$ : cuttings material from young trees, $\left(A_{3}\right)$ : cuttings material from mature trees; concentration of root growth regulator i.e. $B_{1}:$ control, $B_{2}$ : rootone- $F, B_{3}: I B A 100 \mathrm{ppm}, B_{4}: I B A 200 \mathrm{ppm}, B_{5}=I B A$ $\left.500 \mathrm{ppm}, B_{6}=I B A 1000 \mathrm{ppm}\right)$ 
Berdasarkan Tabel 3 dan Gambar 1, pohon nyamplung yang sudah tua masih mampu diperbanyak secara vegetatif stek walaupun keberhasilan masih rendah (16-25\%). Potensi ini dapat digunakan untuk memperbanyak pohon-pohon unggul. Pohon-pohon yang memiliki produktivitas buah dan minyak yang tinggi dapat langsung diperbanyak dengan teknik perbanyakan secara stek.

Tabel (Table) 3. Hasil uji jarak pengaruh umur bahan stek terhadap rata-rata prosen hidup, prosen berakar, jumlah dan panjang akar serta biomasa akar stek nyamplung umur 3 bulan (The effect of cutting source on growth parameters of the cuttings)

\begin{tabular}{|c|c|c|c|c|c|c|c|}
\hline No. & $\begin{array}{l}\text { Bahan stek } \\
\text { (Material of } \\
\text { cuttings }\end{array}$ & $\begin{array}{l}\text { Persen hidup } \\
\text { (Survival } \\
\text { percentage) } \\
\quad(\%)\end{array}$ & $\begin{array}{c}\text { Persen tunas } \\
(\text { Shoot } \\
\text { percentage) } \\
(\%)\end{array}$ & $\begin{array}{l}\text { Persen akar } \\
\quad(\text { Root } \\
\text { percentage) } \\
(\%)\end{array}$ & $\begin{array}{c}\text { Panjang } \\
\text { akar } \\
\text { (Length of } \\
\text { root) } \\
(\mathrm{cm}) \\
\end{array}$ & $\begin{array}{l}\text { Jumlah } \\
\text { akar } \\
\text { (Number } \\
\text { of root) }\end{array}$ & $\begin{array}{c}\text { Biomasa akar } \\
\text { (Biomassa } \\
\text { of root) } \\
\text { (g) }\end{array}$ \\
\hline 1 & $\begin{array}{l}\text { Anakan } \\
\text { (Seedling) }\end{array}$ & $89,17^{\mathrm{a}}$ & $61,67^{\mathrm{a}}$ & $75,00^{\mathrm{a}}$ & $14,54^{\mathrm{a}}$ & $15^{\mathrm{a}}$ & $0,132^{\mathrm{a}}$ \\
\hline 2 & $\begin{array}{l}\text { Pohon } \\
\text { muda } \\
\text { (Young } \\
\text { tree) }\end{array}$ & $75,28^{b}$ & $39,44^{b}$ & $25,00^{b}$ & $9,67^{\mathrm{b}}$ & $10^{\mathrm{b}}$ & $0,094^{b}$ \\
\hline 3 & $\begin{array}{l}\text { Pohon } \\
\text { dewasa } \\
\text { (Mature } \\
\text { tree) }\end{array}$ & $71,39^{b}$ & $27,81^{b}$ & $16,11^{b}$ & $8,54^{\mathrm{b}}$ & $9^{b}$ & $0,100^{\mathrm{ab}}$ \\
\hline
\end{tabular}

Keterangan (Remark): Angka yang diikuti oleh huruf yang sama tidak berbeda nyata pada taraf uji 5\% (DMRT). (Values in rows followed by the same letter are not significantly different at level of $5 \%$ base on Duncan Multiple Range test)

Bahan stek nyamplung termasuk yang tahan terhadap cekaman air. Hal ini ditunjukkan dengan persen stek segar yang masih tinggi, walaupun bahan stek dikumpulkan dari lokasi yang cukup jauh dari tempat pengakaran stek. Bahan stek asal pohon yang sudah berbuah masih mampu bertahan hidup sebanyak $71,39 \%$ pada umur 3 bulan setelah tanam, walaupun hanya $16,11 \%$ yang mampu berakar (Tabel 3). Walaupun respon kandungan auxin antara bahan stek anakan dan pohon tidak berbeda nyata (Tabel 2), namun nisbah $\mathrm{C} / \mathrm{N}$ jaringan pohon dewasa lebih rendah (Tabel 1) dibandingkan $\mathrm{C} / \mathrm{N}$ anakan yang menyebabkan rendahnya kemampuan stek untuk berakar, artinya auxin bukan merupakan penentu tunggal.

Bahan stek dari pohon induk berumur muda menghasilkan persen stek berakar yang tinggi, semakin dewasa kemampuan perakarannya menurun. Fenomena ini terjadi seiring dengan semakin menurunnya kandungan auksin dan nisbah $\mathrm{C} / \mathrm{N}$ dalam bahan stek (Tabel 1). Kandungan $\mathrm{C}$ relatif sama, sedangkan kandungan $\mathrm{N}$ cenderung semakin meningkat.
Nilai nisbah $\mathrm{C} / \mathrm{N}$ bahan stek sangat berpengaruh terhadap pertumbuhan akar stek Heritiera spp. (Das et al., 1997), Thunbergia grandiflora (Hussein, 2008), Rosa multiflora 'Brooks 56' (Hambrick et al., 1991), Shorea leprosula Miq. (Danu, 2009), tetapi tidak dapat diperkirakan secara pasti berapa nilai $\mathrm{C} / \mathrm{N}$ yang terbaik untuk perakaran stek (Struve 1981, diacu dalam Hambrick et al., 1991). Nisbah C/N bahan stek terbaik terhadap perakaran stek Rosa multiflora adalah 12:1 (Hambrick et al., 1991). Pada tanaman Ulnus villosa terjadi perakaran terbaik ketika bahan stek memiliki kandungan gula, karbohidrat total dan aktifitas enzim peroxidase yang tinggi dengan kandungan $\mathrm{N}$ yang rendah (Bhardwaj and Mishra, 2005).

Untuk meningkatkan persen perakaran stek nyamplung dari bahan stek yang sudah dewasa dapat dilakukan rejuvenasi. Teknik rejuvenasi bahan stek antara lain dengan cara: 1) memunculkan tunas adventif dari bagian akar, 2) memotong tunas apikal atau tunas samping kemudian menyemprotnya dengan larutan sitokinin atau gibberellin, 3) mendorong 
tumbuhnya tunas sphaeroblasts pada pohon tua dengan cara memotong cabang atau melakukan pembengkokan batang pada kebun pangkasan, 4) menyambungkan tunas tua dengan tanaman bawah yang berumur muda secara berseri hingga tunas mampu berakar, 5) melakukan subkultur secara berseri dengan teknologi kultur jaringan (Galopin et al. 1996; Hartmann et al. 1997).

\section{A. Proporsi kemampuan berakar bahan stek nyamplung}

Umur pohon induk sangat mempengaruhi porporsi pertumbuhan akar dan tunas stek nyamplung (Tabel 4). Pada umur 3 bulan setelah tanam, masing-masing stek nyamplung memiliki kemampuan perakaran yang berbeda. Tidak semua stek yang ditanam mampu berakar. Bahan stek yang ditanam terdapat stek yang hanya mampu bertunas, stek yang hanya mampu berakar, stek mampu bertunas dan berakar, dan stek tidak mampu bertunas maupun berakar (stek masih segar). Stek nyamplung siap tanam adalah stek yang telah bertunas dan berakar. Stek seperti ini dapat dihasilkan dari bahan stek asal anakan sebesar 55,88\%, asal pancang sebesar $18,33 \%$, dan asal pohon yang sudah berbuah sebesar $10 \%$.

Tabel(Table) 4. Rekapitulasi nilai F hitung pengaruh perlakuan umur bahan stek dan hormon tumbuh terhadap proporsi persen tumbuh stek nyamplung umur 3 bulan (Racapitulation of $F$ calculation value of the effect of cutting source on growth parameters of the nyamplung cuttings on 3 months age)

\begin{tabular}{|c|c|c|c|c|c|c|c|}
\hline \multirow[b]{2}{*}{$\begin{array}{l}\text { Sumber } \\
\text { Keragaman } \\
\text { (Source of } \\
\text { variation) }\end{array}$} & \multicolumn{5}{|c|}{ F Hitung ( $F$-calculation) } & \multicolumn{2}{|c|}{$\begin{array}{c}\text { F Tabel } \\
(F-\text { Table })\end{array}$} \\
\hline & $\begin{array}{l}\text { Segar } \\
(\text { Fresh })\end{array}$ & $\begin{array}{l}\text { Berakar } \\
\text { (Rooting) }\end{array}$ & $\begin{array}{l}\text { Bertunas } \\
\text { (Shooting) }\end{array}$ & $\begin{array}{c}\text { Bertunas dan } \\
\text { berakar } \\
\text { (Shooting and } \\
\text { rooting) }\end{array}$ & $\begin{array}{l}\text { Tanpa tunas } \\
\text { dan akar } \\
\text { (Without } \\
\text { shooting and } \\
\text { rooting) }\end{array}$ & 0,5 & 0,1 \\
\hline $\begin{array}{l}\text { Bahan stek } \\
\text { (Cuttings material) } \\
\text { (A) }\end{array}$ & $15,37 * *$ & $10,68^{* *}$ & $8,54 * *$ & $58,8^{* *}$ & $30,64 * *$ & 3,32 & 5,39 \\
\hline $\begin{array}{l}\text { Zat pengatur tumbuh } \\
\text { (Growth regulator) } \\
\text { (B) }\end{array}$ & 2,35 & 0,91 & 1,72 & 1,16 & 0,23 & 2,53 & 3,70 \\
\hline $\begin{array}{l}\text { Interaksi } \\
\text { (Interaction) }(\mathrm{A} \times \mathrm{B})\end{array}$ & 1,55 & 0,95 & 0,79 & 0,49 & 1,20 & 2,17 & 2,98 \\
\hline
\end{tabular}

Keterangan (Remark): th = tidak nyata pada taraf uji 0,05 (not significantly at 0,05 level)

* = nyata pada taraf uji 0,05 (significantly at 0,05 level)

$* *=$ sangat nyata taraf uji 0,01 (significantly at 0.01 level)

Stek nyamplung yang berpotensi untuk tumbuh (stek berakar tapi belum bertunas) asal anakan sebesar $75 \%$, asal pancang $25 \%$, dan asal pohon yang sudah berbuah sebesar $16,11 \%$. Stek ini dapat tumbuh tunas bila diberikan pupuk daun atau pupuk perangsang pembentukan tunas. 
Tabel (Table) 5. Proporsi pertumbuhan akar dan tunas stek nyamplung umur 3 bulan (Proportion of root and shoot formation of the tested cutting source)

\begin{tabular}{|c|c|c|c|c|c|c|}
\hline No. & $\begin{array}{c}\text { Bahan stek } \\
\text { Source of } \\
\text { cuttings })\end{array}$ & $\begin{array}{c}\text { Segar } \\
(\text { Fresh }) \\
(\%)\end{array}$ & $\begin{array}{c}\text { Berakar } \\
(\text { Rooting) } \\
(\%)\end{array}$ & $\begin{array}{c}\text { Bertunas } \\
(\text { Shooting) } \\
(\%)\end{array}$ & $\begin{array}{c}\text { Bertunas } \\
\text { dan } \\
\text { berakar } \\
\text { (Shooting } \\
\text { and } \\
\text { rooting) } \\
(\%)\end{array}$ & $\begin{array}{c}\text { Tanpa tunas } \\
\text { dan akar } \\
\text { (Without } \\
\text { shooting and } \\
\text { rooting) } \\
(\%)\end{array}$ \\
\hline 1 & $\begin{array}{c}\text { Anakan } \\
(\text { Seedling })\end{array}$ & $89,17^{\mathrm{a}}$ & $18,89^{\mathrm{a}}$ & $6,11^{\mathrm{b}}$ & $55,83^{\mathrm{a}}$ & $8,33^{\mathrm{c}}$ \\
\hline 2 & $\begin{array}{c}\text { Pohon muda } \\
\text { (Juvenile trees) }\end{array}$ & $75,28^{\mathrm{b}}$ & $6,39^{\mathrm{b}}$ & $21,11^{\mathrm{a}}$ & $18,33^{\mathrm{b}}$ & $29,44^{\mathrm{b}}$ \\
\hline 3 & $\begin{array}{c}\text { Pohon dewasa } \\
(\text { Mature tree) }\end{array}$ & $71,39^{\mathrm{b}}$ & $6,11^{\mathrm{b}}$ & $14,72^{\mathrm{a}}$ & $10^{\mathrm{b}}$ & $40,56^{\mathrm{a}}$ \\
\hline
\end{tabular}

Keterangan (Remark): Angka yang diikuti oleh huruf yang sama tidak berbeda nyata pada taraf uji 5\% (DMRT) (Values in rows followed by the same letter are not significantly different at level of $5 \%$ base on Duncan Multiple Range test).

Stek yang agak potensi adalah stek yang sudah bertunas tapi belum berakar. Stek nyamplung yang hanya mampu tumbuh tunas karena proses penyembuhan luka pada stek ini relatif lambat, bahan stek sudah tua, potongan stek rusak atau retak sehingga terjadi pembusukan sebelum terbentuk akar. Stek yang telah membusuk sulit berakar walaupun stek telah bertunas. Stek yang tidak bertunas dan tidak berakar disebabkan jaringan stek sudah dewasa, secara genetik sulit berakar, dan kandungan nutrisi bahan stek sangat rendah (Hartmann et al., 1997). Semakin dewasa bahan stek semakin turun kemampuan menumbuhkan tunas maupun akar walaupun stek tersebut dalam keadaan segar.

\section{KESIMPULAN DAN SARAN}

\section{A. Kesimpulan}

1. Teknik stek dapat diaplikasikan untuk perbanyakan bibit nyamplung (Calophyllum inophyllum L.).

2. Semakin muda umur pohon induk bahan stek cenderung mengandung hormon tumbuh auksin dan nisbah $\mathrm{C} / \mathrm{N}$ yang tinggi, sehingga menghasilkan persentase keberhasilan perakaran stek nyamplung yang tinggi.

3. Bahan stek nyamplung asal anakan dapat menghasilkan stek berakar sebanyak $75 \%$ dengan panjang akar $14,54 \mathrm{~cm}$, jumlah akar 15 buah per stek dan biomasa akar 0,132 gram per stek; bahan stek nyamplung asal pohon belum berbuah dapat menghasilkan stek berakar sebanyak 25\% dengan panjang akar 9,67 cm, jumlah akar 10 buah per stek, dan biomasa akar 0,094 gram per stek; bahan stek nyamplung asal pohon yang sudah berbuah dapat menghasilkan stek berakar $16,11 \%$ dengan panjang akar $8,54 \mathrm{~cm}$, jumlah akar 9 buah per stek, biomasa akar 0,10 gram per stek.

4. Pohon muda (belum berbuah) dan pohon dewasa (sudah berbuah) nyamplung masih mampu berakar (16\% dan 25\%), sehingga teknik stek dapat digunakan untuk memperbanyak pohon-pohon nyamplung terseleksi yang telah memasuki fase reproduksi.

\section{B. Saran}

Pengadaan bibit untuk pembangunan hutan dari klon-klon unggul dapat menggunakan teknik perbanyakan vegetatif (stek). Teknik ini dapat digunakan untuk multiplikasi klon dari pohon induk nyamplung hasil seleksi yang telah memasuki fase reproduksi.

\section{DAFTAR PUSTAKA}

Bustomi, S., T. Rostiwati, R. Sudradjat, B. Leksono, A.S. Kosasih, I. Anggraeni, D. Syamsuwida, Y. Lisnawati, Y. Mile, D. Djaenudin, Mahfudz, E. Rahman. 2008. 
Nyamplung (Calophyllum inophyllum L.): Sumber Energi Biofuel yang Potensial. Badan Penelitian dan Pengembangan Kehutanan. Jakarta.

Bhardwaj, D.R. And V.K. Mishra. 2005. Vegetative propagation of Ulmus villosa: effects of plant growth regulators, collection time, type of donor and position of shoot on adventitious root formation in stem cuttings. New Forests 29 (2): 105 116. (Abstrak).

Danu. 2009. Hubungan antara umur dan tingkat juvenilitas dengan keberhasilan stek dan sambungan pucuk meranti tembaga (Shorea leprosula Miq.). Tesis. Sekolah Pascasarjana, IPB. Bogor.

Das, P., U.C. Basak and A.B. Das. 1997. Metabolic Changes During Rooting in Pre-girdled Stem Cuttings and Air-layers of Heritiera. Botanical Bulletin of Academia Sinica 38: 91-95.

Galopin, G., F. Beaujard and M. Gendraud. 1996. Intensive Production of Juvenile Cuttings by Mother Microplant Culture in Hidrangea macrophylla "Leuchtfeuer". Canadian Journal of Botany. 74: 561-567.

Hambrick, C.E.III., F.T.Jr. Davies and H.B. Perberton. 1991. Seasonal Changes in Carbohydrate/Nitrogen Levels during Field Rooting of Rosa multiflora 'Brooks $56^{\prime}$ hardwood cuttings. Scientia Horticultural 46:137-146.

Hartmann, H.T., D.E. Kester and F.T. Davies, R.L. Geneve. 1997. Plant Propagation: Principles and Practices. Edisi VI. Prentice Hall. Englewood Cliffs. New Jersey.

Heyne, K. 1987. Tumbuhan Berguna Indonesia (terjemahan). Jilid III. Badan Penelitian dan Pengembangan Kehutanan. Jakarta.
Hussein, M.M.M. 2008. Studies on the Rooting and the Consequent Plant Growth on the Stem Cuttings of Thunbergia grandiflora (Roxb. ex Rottl.) Roxb. 2-effect of indole3-butyric acid. World Journal of Agricultural Sciences 4(S): 811-817.

Mandang, Y.I. dan E. Yetty. 1990. Jeni-Jenis Kayu untuk Bahan Baku Industri Kayu Hilir. Prosiding. Makalah Penunjang pada Diskusi Industri Perkayuan. Badan Penelitian dan Pengembangan Kehutanan. Jakarta. 73-88.

Mattjik, A.A. dan Sumertajaya. 2006. Perancangan Percobaan dengan Aplikasi SAS dan MINITAB. Jilid I. IPBPress. Bogor.

Rochiman, K. dan S. Harjadi. 1973. Pembiakan Vegetatif. Departemen Agronomi Fakultas Pertanian IPB. Bogor.

Rostiwati, T. dan Y. Heryati. 2007. Nyamplung (Calophyllum spp.). Asia Pacific Forest Genetic Resources Programme (APFOGEN). Pusat Penelelitian dan Pengembangan Hutan Tanaman. Bogor.

Salisbury FB, Ross CW. 1995. Fisiologi Tumbuhan. Volume ke-1,2,3. Lukman DR, Sumaryono, penerjemah; Bandung: ITB Pr. Terjemahan dari: Plant Physiology.

Salminah, M. 2007. Nyamplung, Harapan Baru Biodiesel Indonesia. Berita Sains dan Teknologi Untuk Hutan Lestari (BESTARI). PUSLITSOSEK. Bogor.

Woodward, A.W., and B. Bartel. 2005. Auxin: Regulation, Action, and Interaction. Invited Review. Annals of Botany 95: 707735 .

Zobel, B. and Talbert, J. 1984. Applied Forest Tree Improvement. Wave Land Press, Inc. Illinois. USA. 